\title{
Dekonstruksi Dikotomi Menggagas Spiritualisasi Human Being dalam Pendidikan Islam
}

\section{Bahar Agus Setiawan}

Dosen program Studi Pendidikan Agama Islam, Fakultas Agama Islam

Universitas Muhammadiyah Jember

Email : baharsetiawan@unmuhjember.ac.id

\begin{abstract}
Submission
Abstract

Track:

Received:

22 Agustus 2019

Final Revision:

30 Agustus 2019

Available online:

25 September 2019

Corresponding

Author:

Education as a conscious and planned effort as stated in the National Education System Act no. 20, 2003 relates to three developmental targets, namely: the development of spiritual power, intelligence and morality. However, the existence of dichotomy in science and education makes the direction of education lose its essential weight. For this reason, such a dichotomy must be deconstructed to produce synergy and integration between intellectual and spiritual entity. Education in general and Islamic education in particular must not be conceived partially, so the core value of education can be realized. The idea of human as a living spiritual entity in Islamic education can be realized by revitalizing and conceptualizing the role and meaning of Islamic education by developing and changing curriculum in both content and purpose, as an effort to entrench spirituality as the basis of orienting Islamic education.

Keywords: dichotomy deconstruction, human being spiritualism, Islamic education

Name \& E-mail Address

Bahar Agus Setiawan

baharsetiawan@unmuhjember.ac.id

Abstrak

Pendidikan sebagai usaha sadar dan terencana dalam undang-undang Sisdiknas nomor 20 tahun 2003 esensinya tertuju pada tiga yaitu pengembangan kekuatan spiritual keagamaan, kecerdasan dan akhlaq mulai. Namun dikotomi baik dalam keilmuan dan pendidikan menjadikan arah pendidikan kehilangan ruh yang bersifat esensial, sehingga dikotomi tersebut harus mampu didekontrusksi yang mampu menghasilkan sinergi dan integrasi antara intelektualitas dengan spiritualitas. Pendidikan dan pendidikan Islam pada khususnya tidak boleh dipahami secara parsial, sehingga core value proses tersebut dapat diwujudkan. Gagasan spiritualisasi human being dalam pendidikan Islam dapat diwujudkan dengan revitalisasi dan konseptualiasasi peran dan makna pendidikan Islam sebagai institusi dengan melakukan pengembangan dan perubahan kurikulum baik dalam muatan, isi dan tujuannya, sebagai upaya untuk membumikan spiritualitas sebagai basic orientasi pendidikan Islam.
\end{abstract}

Keywords: dekonstruksi dikotomi, spiritualisasi human being, pendidikan Islam

\section{PENDAHULUAN}

Kemunculan pemikiran Ian G. Barbour tentang empat perspektif hubungan sians/ilmu dan agama (Waston, 2014), menjadi titik tolak perspektif baru tentang hubungan antara keduanya. Titik tolak fenomena ini tidak lepas hasil inisiasi kemunculan ideologi sekulerisme mampu mendorong dan melahirkan perseteruan yang runcing antara sains dan agama. Perkembangan peradaban Barat, bukan hanya pada tataran makna wilayah an sich, tetapi lebih pada worldview, tidak lepas dari munculnya peristiwa renainsance. Perseteruan antara sains dan agama, rasio dan wahyu, merupakan perwujudan masing-masing pihak untuk menegasikan dan bersikukuh menunjukkan domain dan hegemoninya. Dikotomi keilmuan sebagai sebuah realitas pada peradaban Barat, yang dibangun atas paradigma CartesianNewtonian, menegaskan bahwa rasio sebagai landasan utama. Cogito ergo sum ala Descartes 
merupakan landasan utama hegemoni rasio atas nilai-nilai yang bersifat metafisik (Khoirul Fata \& Mahmudah Noorhayati, 2016). Realitas ini yang kemudian dengan meminjam istilah Hutington, melahirkan benturan peradaban Islam dan Barat.

Modernisme sebagai anak kandung sekulerisme dengan simbol dikotomi ilmu dan agama duduk sebagai pemenang dalam persaingan perebutan hegemoni. Agama tersingkirkan dan hanya menjadi legal formal ruang privat. Dinamika kehidupan dalam berbagai aspeknya dihiasi oleh orientasi logika yang membabi buta sebagai bagian dari simbolisasi dikotomi. Dikotomi ilmu dan agama pada akhirnya berimbas pada seluruh aspek kehidupan masyarakat seperti sosial, politik dan pendidikan pada khususnya. Ditambah lagi dengan adanya berbagai peristiwa dan isu terorisme semakin memberikan legitimasi bahwa dikotomi ilmu dan agama merupakan sebuah keniscayaan yang harus diwujudkan. Agama dianggap sebagai kontributor utama dalam mendorong konflik dan ekstrimisme serta sebagai unsur yang memperkuat terjadinya konflik dalam kehidupan manusia (Davies, 2014). Dampaknya corak perkembangan konseptual dalam dunia pendidikan pada akhirnya memperlihatkan karakter dikotomis yang kongkrit, dalam konteks Indonesia, di era kolonial merupakan bukti nyata bahwa dikotomi menjadi arus utama model pendidikan. Perbedaan pendidikan Barat dan Islam memang tidak lepas dari perbedaan landasan, metode dan lainnya antara Islam dan Barat (Kosim, 2008). Model pendidikan Barat yang dilandasi oleh rasionalitas-materialistik memberikan konsekuensi logis atas pandangan bahwa etika, moral dan value disusun atas dasar rasio manusia (Fatawi, 2015).

Historisitas pendidikan di Indonesia memang tidak bisa dilepaskan dari pengaruh kolonialiasasi yang terjadi. Konsep pendidikan pada saat itu merupakan imitation secara keseluruhan model pendidikan Barat. Meskipun Indonesia sebelum mengalami kolonialisasi telah memiliki tradisi dan kultur pendidikan berbasis Islam (Akhiruddin, 2015), namun popularitasnya kalah mentereng dengan model pendidikan Barat. Seiring dengan gerakan pembaharuan dan kesadaran umat Islam, reformasi dalam bidang pendidikan di Indonesia muncul sebagai bentuk perlawanan atas kolonialisasi (Masruroh dan Umiarso, 2011 : 183). Momentum tergerusnya hegemoni pendidikan ala Barat di Indonesia tereduksi dengan gagasan lembaga pendidikan ala KH. Ahmad Dahlan yang berafiliasi kepada paradigma pendidikan progresif (Ali, 2016), menjadi titik tolak gerakan reformasi dan evolusi pendidikan Islam di Indonesia. Sejarah pendidikan Islam dalam konteks keindonesiaan, memang terlihat corak dikotomisnya. Lembagalembaga pendidikan Islam seperti pesantren, madrasah mempunyai kecenderungan untuk mengajarkan ilmu agama sedangkan untuk ilmu pengetahuan umum menjadi area garapan sekolah umum.

Seiring dengan pengaruh gerakaan pembaharuan dalam dunia Islam, yang kemudian berakibat pada reformasi pendidikan Islam khususnya di Indonesia dengan menampilkan pelajaran umum pada materi pembelajaran meskipun pada kuantitas masih banyak didomonasi oleh pelajaran agama sebagai ciri khas yang melekat pada konseptual pendidikan Islam. Abad 20 menjadi momentum gerakan reformasi dalam pendidikan Islam sehingga mampu mewarnai pendidikan di Indonesia dengan kemunculan lembaga-lembaga pendidikan seperti Gontor, 
Madrasah berbasis negeri, dan model lembaga pendidikan lainnya. Momentum perkembangan konseptualisasi pendidikan Islam di Indoensia dalam menggeser perspektif dikotimi dengan kemunculan model lembaga pendidikan Islam terpadu pasca reformasi (Arifin, 2012 : 30-31).

Merujuk pada landasan dasarnya, perspektif Islam, gagasan mensinegikan ilmu dengan agama, dalam proses pendidikan, menjadi sebuah keharusan agar kedunya saling menguatkan (Bisryi, 2009). Sehingga pendidikan Islam mampu memberikan kontribusi signifikan dan mewarnai perkembangan pemikiran baik dalam ranah teoritis maupun praktis. Pendidikan Islam harus mampu berperan secara dinamis dan produktif (Mahsun, 2013), tidak saja pada evolusi konseptualnya tetapi juga pada kontribusinya dalam membentuk manusia paripurna. Pendek kata, mengakhiri konflik konsep dikotomi dalam dunia pendidikan Islam pada khususnya harus menjadi orientasinya.

$$
\text { Perkembangan bahasan tentang }
$$

kecerdasan mulai dari kecerdasan intelektual sampai kecerdasan spiritual menjadi indikator kongkrit bahwa pendidikan Islam pendidikan Islam bukan hanya sebagai proses penanaman dimensi eskatologis an sich, disisi lain juga pada aspek profan (Zainuddin, 2011). Kontribusi dan tujuan utama pendidikan Islam adalah untuk mengembangkan potensi dan kompetensi manusia sehingga menjadi insan kamil dengan karateristiknya khusus sebagai rahmatan lil alamin dan uswatun hasanah karena peran akhirnya sebagai khalifa fil ardhi (May, 2015, Hayat, 2014). Paradigma baru pendidikan Islam harus mampu menjadi rujukan konsep pendidikan yang komprehensif dan holistik.

\section{Tinjauan Pustaka}

\section{Dekonnstruksi Dikotomi}

Istilah dekonstruksi identik dengan kajian dalam bidang bahasa dan sastra, sehingga pemaknaan atas kata tersebut selalu berkaitan dengan penelitian dalam bidang tersebut. Definisi dekonstruksi secara etimologi yaitu secara leksikal prefiks "de" berarti penurunan, pengurangan, penokohan, penolakan, maka dekonstruksi dapat diartikan sebagai cara-cara pengurangan terhadap konstruksi, yaitu gagasan (Tasnim, 2014). Pemaknaan atas kata dekontruksi tersebut merupakan konteks analisis terhadap teks, kedudukannya sebagai sebuah metode penelitian bahasa dan sastra. Adapun dalam laman KKBI Daring mendefiniskkan pengertian dekonstruksi adalah penataan ulang. Didasarkan pada deskripsi tersebut dekontruksi dapat ditafsirkan sebagai penolakan terhadap gagasan dalam rangka penataan ulang atas paradigma atau pandangan tertentu.

Kata dikotomi atau dichotomy dalam bahasa inggris mempunyai makna pembagian dalam dua bagian, pembelahan dua, bercabang dalam dua bagian, sebagai pembagian di dua kelompok yang saling bertentangan. Ditinjau dalam perspektif terminologis, dikotomi dipahami sebagai pemisahan antara ilmu dan agama yang kemudian berkembang menjadi fenomena dikotomikdikotomik lainnya, seperti dikotomi ulama dan intelektual, dikotomi dalam dunia pendidikan Islam dan bahkan dikotomi dalam diri muslim itu sendiri (split personality). Dikotomi berarti pembagian menjadi dua bagian atau pembagian dua kelompok yang saling bertentangan. Dalam konteks pendidikan, dikotomi bermakna pemisahan antara pendidikan umum dan pendidikan agama. Pemisahan tersebut bukan hanya pada aspek 
pemilahan, tetapi masuk pada tataran pemisahan dalam operasionalnya, seperti pemisahan mata pelajaran umum dan agama, sekolah umum dan agama (madrasah) yang pengelolaannya memiliki kebijakan masing-masing

$$
\text { Merujuk pada deskripsi diatas, }
$$
dekosntruksi dikotomi yang dimaksud dalam tulisan ini adalah penataan ulang atas perspektif pemisahan pendidikan agama dengan pendidikan umum, antara moral dengan intelektual, antara agama dengan ilmu pengetahuan. Pengertian ini apabila disematkan ke dalam pendidikan adalah pemaknaan atas proses pendidikan yang tidak bersifat parsial tetapi bersifat komprehensif sebagai satu kesatuan untuk dalam mencerdaskan sekaligus mengembangkan kepribadian yang unggul sesuai dengan nilai-nilai dan ajaran moral yang berlaku di masyarakat.

\section{Spiritualisasi Human Being}

Istilah spiritualisasi buman being, merupakan istilah yang belum begitu populer. Definisi istilah spiritualisasi buman being dalam paradigma pendidikan Islam di era modern ini masih menjadi tema kajian yang harus terus digali, dibahas dan dikembangkan sehingga dapat menjadi wacana dan paradigma yang mampu berevolusi sebagai konsep pendidikan Islam yang komprehensif. Tataran makna komprehensif bukan hanya sebagai sebuah tema tetapi menemukan bentuk, model, kurikulum yang mampu diimplementasikan dalam proses pendidikan.

Istilah spiritualiasasi secara etimologi dimaknai dan diartikan sebagai pembentukan jiwa atau penjiwaan. Unsur utama dari defnisi spiritualisasi adalah proses pembentukan jiwa atau penjiwaan terhadap nilai-nilai agama Islam. Penekanan konsep spiritualisasi lebih pada proses sebagaimana penekanan terhadap pemaknaan sekularisasi, sehingga domain spiritualiasi adalah kerangka kerja yang digunakan untuk mewujudkan pembentukan atau penjiwaan terhadap normanorma, ajaran dan nilai-nilai agama Islam dalam berbagai bidang kehidupan manusia.

Konsep buman being dalam tulisan ini dimaknai berbeda dengan kata buman, didasarkan pada definisi yang dikutip dari kamus oxford :

"Human often refers to the biological characteristics of people.... and It is also used to to different stages in the development of the buman race"

"Human being is often used when talking about a person's ability to think, feel and be social when compared with animals"

Merujuk pada definisi diatas, buman being lebih menekankan dan memaknai manusia sebagai konsep yang berbeda dari makhluk lainnya serta tidak hanya melihat pada tataran karateristik biologisnya an sich akan tetapi lebih bersifat komprehensif dan holistik. Potensi emosi, fisik, akademik, kreatif, sosial dan spirtual sebagai bagian yang melekat pada konsep buman being. Perspektif al-Qur'an terminologi human being lebih identik dengan istilah al-insan yang menjelaskan totalitas manusia sebagai makhluk jasmani dan ronahi yang memiliki perbedaan antara satu dan lainnya baik dalam fisik, psikis dan intelektualitasnya. Kerangka inilah yang kemudian menunjukkan keistimewaan manusia sebagai penyandang khalifah fil ardhi (Rizal, 2018). Istilah spiritualisasi buman being, dalam pandangan dan perspektif penulis, dapat diartikan sebagai proses transformasi dan internalisasi ajaran dan nilai-nilai dogma agama Islam ke dalam diri manusia yang berguna dalam menjalankan fungsinya sebagai khalifah fil ardhi. Definisi tersebut mengandung pemahaman bahwa ajaran dan nilai dogma agama Islam harus terintegrasi dan meruapakan esensi yang tak terpisahkan atas diri 
manusia.

\section{PEMBAHASAN}

\section{Dekonstruksi Dikotomi Menggagas} Spiritualisasi Human Being dalam Pendidikan

\section{Islam}

Stigma atas dikotomi tidak bisa dilepaskan dari sejarah dua peradaban yaitu Islam disatu sisi dan Barat disisi lain. Elan vital atas kemunculan dikotomi dapat dipastikan lahir atas ketidak harmonisan dan perseteruan yang terjadi antara sains (ilmu pengetahuan) dan agama. Momentum perseteruan antara keduanya mencapai fase puncak ditandai dengan kelahiran sekulerisme sebagai titik pijak hegemoni sains (ilmu pengetahuan)/akal atas agama. Ilmu pengetahuan (sains) pada tahap sebelumnya berada pada wilayah kontrol agama, namun seiring dengan kondisi tersebut, ilmu pengetahuan (sains) mengkonstruksi wilayahnya secara otonom sehingga secara totalitas lepas dari kendali agama.

Pengaruh nyata dalam Islam atas realitas tersebut, kontruksi paradigma dikotomi mulai menggejala ditandai dengan dua kelompok yang saling vis a vis, kelompok tradisionalis di satu sisi dan kelompok modernis di sisi yang lain. Perseteruan keduanya mencoba saling menegasikan eksistensi lawannya. Kelompok tradisionalis menganggap bahwa sains (ilmu pengetahuan) yang merupakan hasil produk peradaban Barat, enggan untuk tidak mengatakan "haram", mempelajari dan mendalami. Kelompok modernis menganggap bahwa agama sebagai metafisik bersifat ilmiahsemu yang tidak berdasarkan fakta yang bersifat empiris.

Problematika yang dihadapi atas fakta dikotomi pada masyarakat Barat sangat berbeda jauh ketika perspektif itu terjadi dan berkembang pada tradisi Islam. Perbedaan ini dipengaruhi oleh konsistensi masyarakat Barat atas ideologi sekulersime dan konsistensi Islam atas tradisi agamanya. Sehingga dikotomi pada masyarakat Barat dianggap sebagai titik tolak kemajuan yang membawa nilai-nilai positif akibat sejarah perseteruannya dengan pihak agama (geraja), namun pada tradisi Islam dianggap sebagai sebuah tatanan yang bersifat negatif.

Dampak negatif atas perkembangan ideologi tersebut, pada akhirnya dunia Islam bergeliat dengan era gerakan pembaharuan. Fakta ini tidak lepas dari fase kemunduran Islam, disamping akibat pengaruh tersebut juga munculnya slogan "pintu ijtihad" telah tertutup. Dinamisasi perkembangan pemikiran Islam mengalami stagnasi tatkala slogan tersebut menjadi populer dan dianggap sebagai keputusan final. Padahal, ijtihad dalam tradisi pemikiran Islam merupakan bentuk aktualisasi perkembangan pemikiran Islam, bukan hanya pada wilayah fiqih an sich, tetapi pada bidang keilmuan lainnya mulai dari politik, ekonomi, sosial, pendidikan dan sains.

Historisitas dekontruksi dikotomi antara sains (ilmu pengetahuan) dan agama mengambil bentuknya ketika gerakan pembaharuan (tajdid) dalam Islam menggejala. Popularitas gerakan ini kemudian dikenal dengan istilah modernisme dalam Islam. Landasan gerakan ini menekankan pada aspek universalitas Islam harus mampu diadaptasikan dengan lingkungan, tanpa harus mereduksi orisinilitas dan otensitas Islam sebagai agama wahyu (Suaidi, 2014).

Efek kongkrit modernisme dalam Islam kemudian memunculkan paradigma kebangkitan Islam. Terlepas dari statemen tersebut, dinamisasi 
perkembangan pemikrian dalam Islam mengalami perekembangan yang signifikasn. Kajian pemikiran keIslaman mendorong munculnya tokoh-tokoh populer pada abad 20 seperti Hasan Hanafi, Muhammad Abduh, Fazlur Rahman, Ismail AlFaruqi dan lainnya yang dianggap sebagai pelopor modernisme dalam Islam, meskipun di era klasik ada sosok Ibn Khaldun, Ibn Sina, Ibnu Batutah, alKhawarizmi dan lainnya. Merujuk pada fakta tersebut, pada dasarnya jejak peradaban Islam telah memberikan gambaran yang jelas tentang hubungan antara sains (ilmu pengetahuan) dan agama.

Modernisme dalam Islam yang berorientasi untuk mendobrak sekat-sekat sains (ilmu pengetahuan) dan agama pada akhirnya mampu menghasilkan paradigma baru pemikiran khususnya dalam konseptualisasi pendidikan Islam yang pada era sebelumnya terkesan termarginal dan kurang berdaya saing. Konferensi dunia pendidikan Islam yang berlangsung di Mekkah pada tahun 1977 menjadi titik tolak gerakan reformasi pendidikan Islam yang menghasilkan gambaran sinergisitas sains dan agama dengan ide kategorisasi pengelompokan ilmu dalam terminologi Islam yaitu perrenial knowledge (pengetahuan abadi) yang didasarkan pada al-Qur'an dan acquired knowledge (pengetahuan yang diperoleh).

Sejalan pasca agenda konferensi international pendidikan Islam tersebut, aura dekontruksi dikotimi semakin menguat ditandai dengan berbagai pelaksanaan reformasi pendidikan Islam tidak hanya pada muatan, tetapi merambah pada ranah pengelolaan untuk melahirkan tingkat daya saing yang tinggi pendidikan Islam. Perubahan kurikulum, rekontruksi manajemen pendidikan Islam, pengembangan sarana prasarana, pengembangan model pendidikan Islam menjadi fakta otentik bahwa reformasi pendidikan Islam menemukan momentumnya.

Gagasan dekontruksi dikotomi keilmuan adalah dengan mensinergikan ilmu dan agama dalam proses pendidikan. Gagasan mensinegikan ilmu dengan agama, dalam proses pendidikan, menjadi sebuah keharusan agar kedunya saling menguatkan, sehingga pendidikan Islam mampu memberikan kontribusi signifikan dan mewarnai perkembangan pemikiran baik dalam ranah teoritis maupun praktis, sehingga pendidikan Islam mampu berperan secara dinamis dan produktif (Mahsun, 2013).

Rekontruksi pendidikan Islam di Indonesia saat ini menunjukkan progres yang sangat signifikan. Kesan adanya dikotomi ilmu pengatahuan dan agama sudah mampu direduksi dengan kemunculan lembaga-lambaga pendidikan dengan citra modern. Modernisasi memberikan pengaruh yang signifikan terhadap perubahan model pendidikan Islam melalui adaptasi tanpa kehilangan identitas keislaman (Tajab, 2014). Realitas tersebut tampak pada pesantren sebagai salah satu model pendidikan Islam khas Indoensia, nampak perubahan pada aspek pengelolaan, metode dan isi kurikulum pesantren (Hasan, 2015, Bashori, 2017, Baidlawi, 2006), sehingga berdampak positif kesan adanya dekontruksi dikotomi dalam pendidikan Islam. Fakta lain atas adanya dekonstruksi dikotomi pendidikan Islam dalam konteks ke Indoensiaan di era modern dengan kemunculan institusi pendidikan tinggi Islam dengan bentuk UIN, pada tingkat sekolah munculnya lembaga pendidikan dengan mengusung konsep "Islam Terpadu". Dikotomi dalam ranah pendidikan Islam saat ini telah menjadi konsep dan 
tema yang usang. Institusi-institusi pendidikan Islam mulai dari tingkat pendidikan anak usia dini (PAUD) hingga perguruan tinggi berlomba-lomba merangkai model sinergisitas antara sains (ilmu pengetahuan) dengan agama dalam proses pendidikan.

Paradigma baru modernisasi pendidikan di Indonesia, memberikan harapan baru terhadap dekonstruksi dikotomi institusi pendidikan. Kekacauan dunia pendidikan telah tereduksi dengan konsep kecerdasan intelektual, emosional dan spiritual sebagai satu kesatuan untuh atas tujuan pendidikan. Pemisahan pendidikan umum dan pendidikan Islam menjadi tema usang berganti dengan sinergisitas keduanya, meskipun masih dalam taraf yang prematur, namun menjadi indikator jelas atas dekontruksi dikotomi tersebut.

Konsep pendidikan merujuk pada UU Sisdiknas nomor 20 tahun 2003 adalah "usaha sadar dan terencana untuk mewujudkan suasana belajar dan proses pembelajaran agar peserta didik secara aktif mengembangkan potensi dirinya untuk memiliki kekuatan spiritual keagamaan, pengendalian diri, kepribadian, kecerdasan, akhlak mulia, serta keterampilan yang diperlukan dirinya, masyarakat, bangsa dan negara”. Kata kunci utama yang terkandung dalam undang-undang tersebut sebagai core value-nya adalah usaha sadar dan terencana, pengembangan diri berkaitan dengan aspek spiritual keagamaan, pengendalian diri dan kepribadian yang terangkum dalam konsep akhlak mulia, kecerdasan atau intelektual, secara tidak langsung menjelaskan secara komprehensif apa dan kemana muara orientasi pendidikan. Mendasarkan pada deskripsi tersebut, maka pada dasarnya paradoks-paradoks yang terjadi dalam proses pendidikan adalah kesalahan dalam memahami, memaknai dan menafsirkan konsep pendidikan itu sendiri.

Pendidikan dengan sangat sederhana dimaknai sebagai urusan pengembangan kognitif an sich dengan legal formal Permendikbud nomor 14 Tahun 2017. Meskipun ada unsur afektif sebagai pendamping, namun terlihat dalam sistem pendidikan di Indonesia ranah kognitif menjadi kebijakan terpenting dan merupakan core dari proses pendidikan dan naifnya lagi hampir sebagaian besar, untuk tidak mengatakan semua, menyetujui realitas tersebut. Kebijakan-kebijakan politis di Indoensia tentang pendidikan selalu berkaitan dengan ranah evaluasi atau penilaian hasil belajar seperti Permendikbud nomor 23 Tahun 2016, Permendikbud nomor 3 Tahun 2017, Permendikbud nomor 4 Tahun 2018 dan UndangUndang Nomor 20 Tahun 2003 itu sendiri terutama pada pasal 59 tentang evaluasi pembelajaran.

Kemunculan pendidikan karakter di era milenial, esensinya merupakan dekontruksi atas legalitas kognitif sebagai unsur dominan dalam pendidikan. Pendidikan karakter (character education) peran inklusif segala komponen seperti keluarga, sekolah dan lembaga sosial terkait dalam mendukung pengembangan karakter positif anak. Adapun karakter berkaitan dengan kualitas moral dan etika yang tergambar pada respon, penalaran dan perilaku emosional. Esensi karakter berkaitan dengan segala kebajikan dan kebaikan seperti sikap hormat, tanggung jawab, dapat dipercaya dan lainnya (WWC, 2014). Elan vital pendidikan karakter tidak lepas dari kekhawatiran atas kondisi moral masyarakat. Sekolah sebagai lembaga pendidikan harus mampu mengambil peran dalam mengajarkan nilai-nilai (Lickona, 1993), bahwa 
tujuan pendidikan bukan hanya untuk keunggulan atas mata pelajaran yang diajarkan, tetapi esensinya merujuk pada kualitas karakter (Shields, 2011).

Besarnya dana pendidikan berdasarkan APBN tahun 2018 seperti yang dikutip dari portal Setkab (setkab.go.id) sebesar 444,131 triliun, dan pada tahun 2019 mengalami kenaikan sebesar 48,4 triliun dengan jumlah 492,555 triliun, menunjukkan bahwa besarnya dana belum mampu memberikan kontribusi yang signifikan terhadap proses pendidikan sebagai institusi formal dalam penanaman karakter. Statemen yang menarik, bahwa tidak ada perdebatan berkaitan dengan kebijakan dan praktek pendidikan, dana untuk penelitian pendidikan, pengembangan instrumen penilaian, sistem akuntabilitas, program pelatihan guru dan pengembangan serta inovasi kurikulum, namun tetap saja arah pendidikan belum secara totalitas diarahkan kepada pengembangan karakter. Terjadi ambiguisitas, disatu sisi keinginan untuk mengejawantahkan pendidikan karakter, tetapi disisi lain karakter hanya sebagai "pemanis" proses pendidikan (Shields, 2011). Kritik atas implementasi pendidikan yang cenderung memarginalkan aspek selain kognitif, selalu menghasilkan perdebatan sengit dan berkepanjangan. Namun ketika realitas dan fenomena berbicara tentang kenakalan anak, tawuran pelajar dan perilaku negatif peserta didik, semua telunjuk secara bersamaan mengarah bahwa hal tersebut merupakan kegagalan pendidikan karakter di sekolah.

Core value pendidikan karakter adalah menumbuhkan generasi muda bangsa yang etis, dan penanaman nilai-nilai humanis yang bersifat universal melalui lingkungan sekolah. Pendidikan karakter merupakan keniscayaan yang disengaja dan didesain yang bersifat proaktif bukan hanya tataran usur yang disematkan kepada materi pembelajaran (Pala, 2011). Perwujudan nyata akan hal tersebut, perlu revitalisasi konseptual peran sekolah dalam pendidikan karakter, sehingga dapat secara maksimal menunjukkan kontribusinya akan hal tersebut. Keberlanjutan atas realitas tersebut, sekolah dalam kerangka implementasi pendidikan karakter harus dimaknai secara esensial bukan parsial. Pemaknaan secara parsial akan mereduksi peran sekolah dalam melaksanakan pendidikan karakter.

Keinginan atas pelaksanaan pendidikan karakter di sekolah perlu ada proses moral conditoning yang kemudian pada taraf selanjutnya, sekolah dibentuk sebagai sebuah moral training area. Desain tersebut merupakan konsep yang bersifat sistemik dalam pengembangan kecerdasan moral sehingga peserta didik dapat memiliki kompetensi kecerdasan sekaligus karakter (Setiawan, 2013). Pendidikan karakter sejatinya terus dikembangkan dengan mengintegrasikan dasar utamanya yaitu spiritualitas.

Pendidikan agama Islam yang dimaknai pada tiga perspektif sebagaimana disinggung, sejatinya dimaknai bukan hanya sebagai mata pelajaran dan institusi pendidikan an sich, tetapi harus dimaknai sebagai sebuah esensi yaitu value atau nilai. Pemakanaan pendidikan Islam sebagai proses penanaman value atau nilai sangat selaras dengan paradigma pendidikan karakter yang memiliki popularitas di era modern seperti yang dijelaskan pada deskripsi diatas.

Peristiwa penganiayaan yang berimbas memunculkan tagar pray for Audrey yang baru saja terjadi, memberikan hantaman keras kepada dunia pendidikan. Penganiaya dan teraniaya yang 
merupakan peserta didik aktif dana masih dibawah umur, membuat pendidikan menjadi objek sasaran kritik masyarakat luas. Mempertanyakan peran institusi pendidikan dengan konsepnya, kurikulum, tenaga pendidik dan perspektif yang sangat "keterlaluan" tentang kegagalan dunia pendidikan dengan pendidikan karakternya. Realitas tersebut merupakan hak dan kebebasan masyarakat dalam memberikan sebuah pandangan atas segala sesuatu yang terjadi dalam dunia pendidikan. Problematika untuk secara utuh atas pendidikan karakter di sekolah, memang tidak bisa dilepaskan dari historisitas pendidikan di Indonesia. Dikotomi pendidikan di Indonesia secara khusus atas institusi pendidikannya yaitu umum dan berbasis Islam merupakan gambaran kongkrit, bahwa realitas tersebut benar merupakan fakta yang tidak dapat disanggah. Penegasian atas fakta tersebut hanya merupakan pengingkaran terhadap realitas yang ada. Aspek legalitas formal baik dari undangundang, peraturan pemerintah, peraturan menteri dan lainnya, memberikan penegasan secara kongkrit atas kenyataan tersebut dimana institusi pendidikan umum mengedepankan intelektualitas, institusi pendidikan Islam lebih ke arah spiritualitas.

Revitalisasi dan rekonseptualisasi peran dan makna pendidikan harus menjadi perhatian utama para pengambil kebijakan. Ruh pendidikan harus dikembalikan kepada track yang jelas dan merujuk pada esensi dan inti orientasi pendidikan. Sistem pendidikan pasca modern yang telah kehilangan nilai-nilai keagamaan sebagai elemen dasar jiwa manusia, nilai ketuhanan dan akhlaq harus dikembalikan kepada fitrahnya sebagai penghasil manusia yang beradab (Sulaiman, Ahmad, Hilmi, Basah, \& Ismail, 2011).

Pendidikan Islam bukan hanya sebagai proses penanaman dimensi eskatologis an sich, disisi lain juga pada aspek profan (Zainuddin, 2011). Kontribusi dan tujuan utama pendidikan Islam adalah untuk mengembangkan potensi dan kompetensi manusia sehingga menjadi insan kamil dengan karateristiknya khusus sebagai rabmatan lil alamin dan uswatun hasanah karena peran akhirnya sebagai khalifa fil ardhi (May, 2015, Hayat, 2014). Konsep insan kamil ini ide dasarnya adalah bahwa tujuan pendidikan Islam adalah menciptakan amalus-solikh baik dalam bentuk kesalehan individu maupun kesalehan sosial (Sunhaji, 2016). Implementasi pendidikan Islam yang bersifat holistik dan komprehensif menjadi sebuah keniscayaan (Mustakim, 2012). Sasaran dan pelaku utama pendidikan adalah manusia bukan hanya dalam kerangka biologis (human), tetapi pada konteks manusia sebagai makhluk sosial yang bisa berfikir dan mempunyai perasaan (human being) (Rayan, 2012). Identitas dari konsep buman being dalam proses pendidikan Islam adalah qalbu dan hati sebagai landasan utamanya yang berbeda dengan model pendidikan Barat (Nasir \& Ismail, 2015). Pendeknya, pendidikan Islam mampu menciptakan dan meningkatkan spritualitas buman being sebagai core pendidikan Islam.

Pendidikan Islam mampu memposisikan diri sebagai agent of change, dalam hal islamisasi ilmu pengatahuan. Pendeknya proses dekontruksi adalah proses Islamisasi sains/ilmu pengetahuan adalah mengintegrasikan nilai-nilai Islam ke dalam ilmu pengetahuan (Bakar \& Siregar, 2004). Kontribusi spider web ala Amin Abdullah menjadi gambaran nyata bahwa dikotomi keilmuan merupakan hal yang tidak ada dalam Islam disatu sisi, sedangkan disisi lain konsep tersebut mampu memberikan citra Islamisasi ilmu pengetahuan (Siregar, 2014). 
Islamisasi ilmu pengetahuan diperlukan dalam konteks pendidikan Islam, sebagai problem solving terhadap dikotomi-dualisme, pendidikan Barat disatu pihak dan pendidikan Islam di lain pihak (Hidayatullah, 2013). Islamisasi Ilmu disisi yang lain juga dapat berdampak pada tujuan pendidikan itu sendiri, sehingga pendidikan bukan hanya bersifat material tapi juga transenden sebagai wujud pengesaan Tuhan (Fauzi, 2017). Tujuan ini tidak lepas dari esensi agama itu sendiri bahwa mampu mempengaruhi tingkah laku manusia (human being), agama sebagai way of life (Ismail, Othman, \& Dakir, 2011). Proses pendidikan Islam menghendaki meningkatnya kecerdasan rasional dan spiritual secara bersama.

Merujuk pada deskripsi diatas, identitas pendidikan Islam sangat erat sekali dengan spiritualitas. Manusia sebagai kombinasi antara ruh dan jasad, dengan berbagai potensi yang dimiliki baik positif atau negatif, maka pendidikan Islam harus mampu mengembangan kecerdasan spiritual (Hamzah, 2010). Spiritualitas manusia atau dengan istilah yang lebih populer yaitu spiritualitasasi buman being, menjadi arus utama atas paradigma rekontruksi pendidikan Islam. Spiritualitas bukan religiusitas, keduanya memiliki dimensi yang berbeda. Religiusitas lebih pada kontek dasar teologis, sedangkan spiritualitas berfungsi untuk membantu manusia dalam memahami pengalaman hidup (Riyadi, 2015). Pendidikan Islam dalam implementasinya harus mampu memberikan pembelajaran terkait hal tersebut.

Perubahan konseptual yang mampu mensinergikan dengan perspektif tersebut adalah dengan pengembangan dan perubahan kurikulum pendidikan Islam. Konsep pendidikan Islam masa kini adalah pendidikan yang berkaitan dengan berbagai unsur kehidupan. Kemajuan pendidikan Islam tidak bisa lepas dari umat islam itu sendiri disatu sisi, sedangkan umat Islam dapat maju apabila pendidikan Islam mengalami kemajuan (Subhan, F. 2013). Perubahan dan pengembangan kurikulum pendidikan Islam dalam seluruh pengertiannya, sebagai sebuah akselerasi dalam mewujuhkan cita-cita tersebut. Pengembangan kurikulum pendidikan Islam dapat merujuk pada 5 model pengembangan kurikulum sebagai landasan arah pengembangannya (Hasan, 2013).

Kurikulum pendidikan Islam dalam terminologi al-Qibsi yaitu ijbari dan ikhtiyari (Maksum, 2014), harus dikembang secara bersinergi dan terintegrasi. Masing-masing jenis kurikulum bukan sebagai ranah pelengkap, tetapi menjadi satu kesatuan utuh sehingga pengembangan kurikulum pendidikan Islam bersifat komprehensif dan mampu mendukung tujuan pendidikan dalam perspektifnya. Kurikulum pendidikan Islam harus mampu mewujudkan sisi intelektual, emosional dan spiritual secara bersamaan.

Pengembangan kurikulum pendidikan Islam yang tepat akan melahirkan motivasi maksimal bagi peserta didik. Kurikulum sebagai blue print, dalam konteks ini pendidikan Islam, harus mampu mengakomodir minat dan bakat peserta didik selaras dengan lingkungan (Little, 2012). Pengembangan kurikulum harus mampu didukung oleh sumber daya yang kompeten, sehingga implementasinya dapat direalisasikan dan dilaksanakan secara tepat. Sejalan dengan deskripsi tersebut, kurikulum sebagai sarana membantu peserta didik dalam memperoleh berbagai pengetahuan harus dikembangkan dengan baik dan tepat (Noraini Hashim \& Langgulung, 2008). 
Pengembangan kurikulum dalam rangka meniti kualitas dan kemajuan pendidikan Islam, harus mampu memahami pendidikan Islam baik dalam kerangka retrospektif dan prospektif (Maidar, 2015), sehingga modernisasi yang diinginkan dalam pendidikan Islam tidak kehilangan ruhnya. Modernisasi dengan agenda reformasi dalam rangka mengembangkan pendidikan Islam adalah sebagai upaya membangun pendidikan islam yang ideal sehingga mampu melahirkan output yang mempunyai spiritualitas yang tinggi sehingga mampu mewujudkan konsep baldatun tayyibatun wa rabbun ghofur. Peranan kurikulum yang begitu signifikan dalam mewujudkan proses spiritualiasasi human being dalam pendidikan, harus benar-benar mampu memfasilitasi terbentuknya tujuan tersebut. Implementasi dan penilaian atas pembumian kurikulum dalam proses pendidikan jangan hanya dipahami sebagai sebuah nilai dalam makna prestasi kognitif tetapi lebih pada nilai yang dimaknai secara filosofis.

Pengembangan kurikulum pendidikan agama Islam harus bersifat multidimensional. Pendidikan agama dan khususnya pendidikan agama Islam sebagai sebuah mata pelajaran mempunyai karateristik yang different (berbeda) daripada mata pelajaran lainnya. Tujuan Pendidikan agama Islam dalam konteks pembelajaran bukan hanya berkaitan dengan konsep pencapaian tahapan Higher Order Thinking Skill (HOTS) dalam mengembangkan aspek kognitif peserta didik, tetapi ranah esensial dari pendidikan agama Islam adalah Spiritual Order Skill (SOS), kemampuan pengembangan intuisi peserta didik berkaitan dengan aspek spritualitas. Realitas tersebut tidak lepas dari core value agama Islam yaitu keimanan dan ketaqwaan.

\section{KESIMPULAN}

Berdasarkan uraian diatas secara keseluruhan dapat disimpulkan bahwa : pertama, dekonstruksi dikotomi atas ilmu dan agama, intelektualiatas dan spiritualitas perseteruan antara keduanya harus mampu direduksi sehingga menjadi unsur yang bersinergi dan terintegrasi dalam pendidikan Islam; kedua, perlu adanya revitaliasi dan rekonseptualiasasi peran dan makna pendidikan sehingga menjadikan spiritualisasi buman being sebagai tujuan utama; dan ketiga; pengembangan dan perubahan muatan, isi dan tujuan kurikulum dapat dijadikan sarana kongkrit dalam mewujudkan spiritualiasai buman being dalam pendidikan Islam.

\section{DAFTAR PUSTAKA}

Ahmad Munawar Ismail, Mohd Yusof Othman, \& Jawiah Dakir. (2011). The Development of Human Behavior: Islamic Approach. Jurnal Hadhari.

Akhiruddin, K. (2015). Lembaga Pendidikan Islam di Nusantara. Jurnal TARBIYA.

Ali, M. (2016). Membedah Tujuan Pendidikan Muhammadiyah. Profetika, Jurnal Studi Islam.

Baidlawi, H. M. (2006). Modernisasi Pendidikan Islam ( Telaah Atas Pembaharuan Pendidikan di Pesantren). Tadris.

Bakar, A., \& Siregar, A. (2004). Islamisasi ilmu pengetahuan. Fikrah.

Bashori, B. (2017). Modernisasi Lembaga Pendidikan Pesantren. Jurnal Ilmu Sosial Mamangan. https://doi.org/10.22202/mamangan.1313

Bisryi, H. (2009). Mengakhiri Dikotomi Ilmu Dalam Dunia Pendidikan. Jurnal Forum Tarbiyah.

Davies, L. (2014). One size does not fit all: Complexity, religion, secularism and education. Asia Pacific Journal of Education. 
https://doi.org/10.1080/02188791.2013.875 647

Fatawi, I. (2015). Problematika Pendidikan Islam Modern. El-Hikam Volume VIII Nomor 2 Juli Desember.

FAUZI, A. (2017). Integrasi Dan Islamisasi Ilmu Dalam Perspektif Pendidikan Islam. Jurnal Pendidikan Islam Uhamka.

Hamzah, R. (2010). Spiritual Education Development Model. Journal of Islamic and Arabic Education.

Hasan, M. (2015). INOVASI DAN MODERNISASI PENDIDIKAN PONDOK PESANTREN. KARS A: Jurnal Sosial Dan Budaya Keislaman. https://doi.org/10.19105/karsa.v2312.728

Hasan, M. S. (2013). PENGEMBANGAN KURIKULUM PENDIDIKAN AGAMA ISLAM. Dinamika Ilmu.

Hayat, H. (2014). Pendidikan Islam dalam konsep prophetic intelligence. Jurnal Pendidikan Islam. https://doi.org/10.14421/jpi.2013.22.379400

Hidayatullah, S. (2013). ISLAMISASI ILMU DALAM PERSPEKTIF FILSAFAT ILMU. Jurnal Filsafat. https://doi.org/10.22146/jf.32969

Khoirul Fata, A., \& Mahmudah Noorhayati, S. (2016). SEKULARISME DAN TANTANGAN PEMIKIRAN ISLAM KONTEMPORER. MADANLA.

Kosim, M. (2008). ILMU PENGETAHUAN DALAM ISLAM (Perspektif FilosofisHistoris). Jurnal TADRIS.

Lickona, T. (1993). The Return Of Character Education. Educational Leadership.

Little, C. A. (2012). Curriculum as motivation for gifted students. Psychology in the Schools. https:// doi.org/10.1002/pits.21621

Mahsun, A. (2013). Pendidikan Islam Dalam Arus Globalisasi Sebuah Kajian Deskriptif Analitis. Episteme.

Maidar, M. (2015). PEMBARUAN PENDIDIKAN ISLAM: TELAAH RETROSPEKTIF DAN PROSPEKTIF. Jurnal Ilmiah Islam Futura. https://doi.org/10.22373/jiif.v15i1.553

Maksum, E. 'Afifah. (2014). konsep Kurikulum Pendidikan Islam Menurut al-Qabisi Dalam Kitab
"Ahwal al-Muta'allim wa Abkam al-Mu'allimin wa al-Muta'allimin." Yogyakarta: Universiti Islam Sunan Kalijaga.

https://doi.org/10.1007/s13398-014-01737.2

May, A. (2015). Melacak Peranan Tujuan Pendidikan dalam Perspektif Islam. TSAQAFAH. https://doi.org/10.21111/tsaqafah.v11i2.266

Mohd Norzi Nasir, \& Ahmad Yani Ismail. (2015). Qalbu, Hati Dan Pendidikan Menurut Pandangan Alam Barat Dan Pandangan Alam Islam. In INTERNATIONAL RESEARCH MANAGEMENT \& INNOVATION CONFERENCE (IRMIC 2015).

Mustakim, M. (2012). ONTOLOGI PENDIDIKAN ISLAM (Hakikat Pendidikan dalam Perspektif Islam). At-Tajdid: Jurnal Ilmu Tarbiyah.

Noraini Hashim, C., \& Langgulung, H. (2008). Islamic Religious Curriculum in Muslim Countries: The Experiences of Indonesia and Malaysia. Bulletin of Education \& Research.

Pala, A. (2011). The Need for Character Education. International Journal of Social Sciences and Humanity Studies.

Parluhutan Siregar. (2014). INTEGRASI ILMUILMU KEISLAMAN DALAM PERSPEKTIF M. AMIN ABDULLAH. MIQOT: Jurnal Ilmu-Imu Keislaman. https://doi.org/10.30821/miqot.v38i2.66

Rayan, S. (2012). Islamic Philosophy of Education. International Journal of Humanities and Social Science.

Riyadi, I. (2015). INTEGRASI NILAI-NILAI KECERDASAN EMOSIONAL DALAM KURIKULUM PENDIDIKAN AGAMA ISLAM DI SMA: PERSPEKTIF DANIEL GOLEMAN. HUNAFA: Jurnal Studia Islamika.

Rizal, S. (2018). MELACAK TERMINOLOGI MANUSIA DALAM ALQURAN. Jurnal AtTibyan: Jurnal Ilmu Alquran Dan Tafsir. https://doi.org/10.32505/tibyan.v2i2.391

Setiawan, D. (2013). Peran Pendidikan Karakter dalam Mengembangkan Kecerdasan Moral. Jurnal Pendidikan Karakter.

Shields, D. L. (2011). Character: As the aim of education. Pbi Delta Kappan. https://doi.org/10.1177/0031721711092008 
10

Suaidi, S. (2014). ISLAM DAN MODERNISME. ISLAMUN A: Jurnal Studi Islam. https://doi.org/10.19105/ISLAMUNA.V1I1 .558

Subhan, F. (2013). KONSEP PENDIDIKAN ISLAM MASA KINI. IPI, a(2).Subhan, F. (2013). KONSEP PENDIDIKAN ISLAM MASA KINI. IPI.

Sulaiman, S. H., Ahmad, I. F., Hilmi, A. M. M., Basah, I. K., \& Ismail, K. (2011).

MENGEMBALIKAN 'RUH' DALAM PENDIDIKAN: NILAI YANG HILANG DALAM PENDIDIKAN MASA KINI. In 2nd International Conference on Islamic Education 2011.

Sunhaji. (2016). The implementation of integrated learning in the islamic religion education as to grow the religiosity and faith of learners. International Journal of Humanities and Social Science.

Tajab, M. (2014). SINTESA ATAS DIKOTOMI PENDIDIKAN ISLAM. At-Tajdid: Jurnal Ilmu Tarbiyah.

Tasnim, Ahmada. (2014, 13 November). Teori Dekonstruksi dan Penerapannya. Diperoleh 7 April 2019, dari https://www.academia.edu/19224832/TEO $\underline{\mathrm{RI}}$ DEKONSTRUKSI DAN PENERAPANN $\underline{\mathrm{YA}}$

Waston. (2014). HUBUNGAN SAINS DAN

AGAMA: Refleksi Filosofis atas Pemikiran Ian G. Barbour. PROFETIKA, Jurnal Studi Islam.

https://doi.org/https://doi.org/10.23917/pr ofetika.v15i1.1968

WWC. (2014). Definition: Character Education. What Works Clearinghouse.

Zainuddin, M. (2011). PARADIGMA PENDIDIKAN ISLAM HOLISTIK. ULUMUNA. https://doi.org/10.20414/ujis.v15i1.210

Undnag-Undang Nomor 20 Tahun 2003

Tentang Sistem Pendidikan Nasional (SISDIKNAS).

Permendikbud Nomor 14 Tahun 2017 Tentang Ijazah dan Sertifikat Hasil Ujian Nasional (SHUN).

Permendikbud Nomor 23 Tahun 2016
Tentang Standar Penilaian Pendidikan.

Permendikbud Nomor 3 Tahun 2017

Tentang Penilaian Hasil Belajar Oleh Pemerintah dan Penilaian Hasil Belajar oleh Satuan Pendidikan.

Permendikbud Nomor 4 Tahun 2018 Tentang Penilaian Hasil Belajar oleh Satuan Pendidikan dan Penilaian Hasil Belajar oleh Pemerintah. 
